\title{
Two Times Yearly
}

National Cancer Institute

\section{Source}

National Cancer Institute. Two Times Yearly. NCI Thesaurus. Code C98861.

Two times per year. 